\title{
Timing of vessel formation in twigs and trunks in relation to porosity and leaf flushing
}

\author{
AUTHOR(S): \\ Takahashi, Sayaka; Takahashi, Erina
}

\section{CITATION:}

Takahashi, Sayaka ...[et al]. Timing of vessel formation in twigs and trunks in relation to porosity and leaf flushing. IAWA Journal 2016, 37(1): 16-27

\section{ISSUE DATE:}

2016-08-23

URL:

http://hdl.handle.net/2433/216362

\section{RIGHT:}

This is the accepted version of the following article which has been published in final form at

http://dx.doi.org/10.1163/22941932-20160118; ; The full-text file will be made open to the public on 01 January 2018 in accordance with publisher's 'Terms and Conditions for Self-Archiving'.; This is not the published version. Please cite only the published version.; この論文は出版社版でありません。引用の際には出版社版をご確認ご利用ください。 
S. Takahashi \& E. Takahashi - 1 -

Timing of vessel formation in twigs and trunks in relation to porosity and leaf flushing

Sayaka Takahashi ${ }^{1}$ and Erina Takahashi ${ }^{2}$

${ }^{1}$ Research Institute for Sustainable Humanosphere, Kyoto University, Uji,

Kyoto 611-0011, Japan

${ }^{2}$ Faculty of Life and Environmental Science, Shimane University,

Nishikawatsu-cho Matsue-shi Shimane, 690-8504, Japan

Corresponding author: e-mail sayaka takahashi@ rish.kyoto-u.ac.jp 
S. Takahashi \& E. Takahashi - 2 -

\section{Abstract}

In order to understand the coordination of leaf phenology and functional xylem anatomy, the timing of vessel wall lignification in twigs and stems in relation to leaf appearance was studied in nine species with different porosity patterns. Cylindrical stem cores and twigs were collected from early spring through late summer from deciduous (Quercus serrata, Liquidambar styraciflua, and Acanthopanax sciadophylloides), and evergreen (Castanopsis cuspidata; Cinnamomum camphora, Ilex pedunculosa, Symplocos prunifolia, Quercus glauca and Quercus myrsinifolia) species in a temperate forest. The first-formed twig vessels lignified at the time of leaf appearance or before in all species. The timing of stem vessel lignification in relation to leaf appearance in semi-ring-porous deciduous species was overlapping with that of ring-porous deciduous species and diffuse-porous deciduous species. Evergreen species showed a great variation in the timing of stem vessel lignification, relative to leaf flushing. The main conclusions are that 1) Vessel lignification occurs much earlier in twigs than in trunks of the same trees, with hardly any overlap between the two; 2) Deciduous trees do not differ much from evergreen species, but there is a weak tendency for evergreen species to have later vessel differentiation than deciduous species; 3) The timing of vessel formation shows little relation with porosity patterns and overlaps between diffuse-porous and ring-porous species. This suggests a much greater intergradation of timing of vessel formation in species of different porosity pattern in evergreen and deciduous species than recognized in the literature.

Keywords: Vessel arrangement, lignification, leaf phenology, functional ecology, evergreen, deciduous. 


\section{S. Takahashi \& E. Takahashi - 3 -}

\section{Introduction}

This study attempts to clarify how variation in vessel porosity affects the timing of vessel formation in relation to leaf appearance. Temperate broad-leaved trees are evergreen or deciduous and may show different wood porosities (Wheeler et al. 1989; Hayashi 1991; Itoh 1995). The differences in the size and distribution of water-conducting cells are related to variations in the phenology of organ development and the seasonal efficiency of water conduction. Porosity patterns themselves show gradations and overlap. Many species range from diffuse-porous to semi-ring-porous, or from ring-porous to semi-ring-porous (Wheeler et al. 1989) and show a considerable plasticity in their xylem (Scholz et al. 2014).

Previous studies revealed that the timing of vessel formation in relation to leaf appearance in typical ring-porous deciduous species differs from that in typical diffuse-porous species (Ladefoged 1952; Suzuki et al. 1996, 2000; Takahashi et al. 2013, 2015). The first-formed vessels, which develop new rings adjacent to the annual ring border, mature around the time of leaf appearance in stems of ring-porous species (Zasada \& Zahner 1969; Suzuki et al. 1996, 2000; Sass-Klaassen et al. 2011; González-González et al. 2013; Takahashi et al. 2013; Kudo et al. 2015). In contrast, stem vessels of diffuse-porous species mature more than two weeks after leaf appearance (Suzuki et al. 1996, 2000; Čufar et al. 2008; Takahashi et al. 2013).

The wide vessels of the pore-zone in ring-porous deciduous species are known to transport water just in the one growing season (Greenidge 1955; Chaney \& Kozlowski 1977; Ellmore \& Ewers 1986; Utsumi et al. 1999; Umebayashi et al. 2008), while in diffuse-porous deciduous species vessels in several rings adjacent to the cambium retain their water transport ability for a number of years (Greenidge 1955; Chaney \& Kozlowski 1977; Utsumi et al. 1998; Umebayashi et al. 2008). The time of stem vessel formation relative to leaf appearance is closely related to water distribution pattern within annual sapwood rings in ring-porous and diffuse-porous deciduous species (Ladefoged 1952; Lechowicz 1984; Suzuki et al. 1996; Takahashi et al. 2013).

The above-mentioned studies on seasonal changes in vessel formation in relation to leaf phenology and water distribution patterns in the sapwood rings lead to the hypothesis that different porosities affect the timing of vessel formation in relation to leaf appearance. In this study, we tested this hypothesis in a 
number of species representing a wide range of porosities, aiming to clarify the coordination between leaf phenology and functional xylem anatomy. In particular, the seasonal relationship between leaf appearance and twig and stem vessel formation was studied in nine tree species with different wood porosity and leaf habits growing together in the same temperate forest stand.

\section{Materials and methods}

\section{Study site and sampled trees}

The study was conducted in a secondary forest of deciduous and evergreen trees at the Kamigamo Experimental Forest Station ( $35^{\circ} 04^{\prime} \mathrm{N}, 135^{\circ} 46^{\prime} \mathrm{E}, 109-225 \mathrm{~m}$ above sea level) of Kyoto University in Japan. The mean annual temperature over a 30 -year period was $14.7^{\circ} \mathrm{C}$, with the highest temperature observed in August $\left(31.8^{\circ} \mathrm{C}\right)$ and the lowest in January $\left(-0.9^{\circ} \mathrm{C}\right)$. The mean annual precipitation was 1,523 mm (data from 1976 to 2005, Forest Research Station of Graduate School of Agriculture, Kyoto University 2007).

This study included observations performed on nine tree species with differing leaf habits (deciduous and evergreen) and different types of vessel porosities, from ring-porous to diffuse-porous (Table 1; Fig. 1 \& 2). Porosity patterns themselves show gradations and overlap. Types of vessel porosities in this study were classified according to Wheeler et al. (1989), the FFPRI website, and the InsideWood website. The type of radial-porous was defined as suggested by Gasson (1985) and Noshiro \& Sasaki (2011). Castanopsis cuspidata is characterized as a (semi-)ring-porous to radial-porous species. Evergreen diffuse-porous species are categorized as diffuse-porous with very weak to more pronounced semi-ring-porous tendencies. The sampled trees were selected from individuals with a diameter at breast height ranging from 12 to $56 \mathrm{~cm}$, and a height between 7 and $29 \mathrm{~m}$, with relatively straight stems. Liquidambar styraciflua and Quercus myrsinifolia individuals were planted trees.

\section{Sampling}

Sampling for vessel formation was performed repeatedly during the entire growing season through wood cores and twig sampling from three to six trees of each examined species. Twig samples were 
collected biweekly between March 14 and June 6 in 2006. Stem samples were collected biweekly between March 14 and June 20, and monthly between July 4 and August 29, in 2006.

Cylindrical wood core samples with a diameter of $7 \mathrm{~mm}$ and a length of $20 \mathrm{~mm}$ were collected at breast height (1.3 $\pm 0.3 \mathrm{~m}$ above the ground) using an increment borer (Mattson, Mora, Sweden) from each tree (Takahashi et al. 2008).

Twigs with sun-exposed leaves were collected from each tree using a 12-m-long pruner or by climbing up the trunk and using a 3-m-long pruner. Twigs that had grown within the previous year were regarded as 1-year-old twigs. In Acanthopanax sciadophylloides, we observed vessel formation in 1-year-old twigs and occasionally in 2- to 4-year-old twigs at $0.5-1.5 \mathrm{~cm}$ below the bud base. Stem cores and twigs were fixed in 3\% aqueous glutaraldehyde soon after sampling.

\section{Assessment of vessel formation in cores and twigs}

Transverse sections with a thickness of 15-30 $\mu \mathrm{m}$ were cut from each twig or stem sample using a sliding microtome (Yamato TU-213; Saitama, Japan). The sections were double-stained with $1 \%$ safranin and $1 \%$ fast green (Sass 1951) for light microscopic study.

Vessel lignification occurs between cell wall deposition and the disintegration of the end walls (Imagawa \& Ishida 1972; Wakuta et al. 1973; Fukushima et al. 2003; Fromm 2013). Lignification of the first-formed vessels in the current growth ring, often adjacent to the annual ring border, was determined by the presence of red color from safranin staining (Sass 1951; Imagawa \& Ishida 1972; Takahashi et al. 2008). If lignification was not clear after double staining, a phloroglucinol-hydrochloric acid reaction was used (Takahashi et al. 2008). The lignification date was defined as the time when the lignification of almost all (more than $80 \%$ ) of the first-formed vessels was observed, tangentially using 2-3 mm long transverse sections.

When enlargement of the first-formed vessels but no lignification of the walls in stems was found by June 20 or July 4, and lignification of the vessels was observed in August 1 or 29, the date of the lignification was judged to be two weeks later than June 20 or July 4, respectively. In two trees of Quercus myrsinifolia, enlargement of the first-formed vessels in the stem was found by August 1, and the vessel lignification date was judged to be two weeks later than August 1. 
S. Takahashi \& E. Takahashi - 6 -

\section{Observation of leaf phenology}

The leaves of each sampled tree were examined weekly using binoculars (Nikon $8 \times 30,8.8^{\circ} \mathrm{WF}$; Tokyo, Japan) and photographed in situ on the selected trees and sampled twigs. Leaf appearance was defined at the shoot level, as the date when the lamina separated from the shoot axis (Kikuzawa 1983). We observed the first flush of leaves in spring weekly between 29 March and 20 June, 2006. The leaf appearance date was defined as the time when almost all (more than $80 \%$ by visual estimate) of flush leaves appeared.

\section{Results}

Timing of twig vessel lignification in relation to leaf appearance

The lignification of the first-formed twig vessels was observed concurrently with leaf appearance in a ring-porous deciduous Quercus serrata, and 0-3 weeks before leaf appearance in a diffuse-porous deciduous Liquidambar styraciflua (Fig. 3). Twig vessel lignification occurred 0-1 week before leaf appearance in Acanthopanax sciadophylloides; 2 weeks before to 1 week after leaf appearance in evergreen species (Fig. 3). In twigs, overall, the time of the first-formed vessel lignification was close to the time of leaf appearance and ranged between 3 weeks before and 1 week after leaf appearance (Fig. $3)$.

\section{Timing of stem vessel lignification in relation to leaf appearance}

The timing of lignification in the first-formed stem vessels is summarized in Figure 4, and ranges from nearly simultaneous with leaf flush up to 15 weeks after leaf appearance. There appears to be a strong overlap between deciduous species, although the total range in timing relative to leaf flush is wider in evergreen species than in deciduous ones. There is hardly any relationship between type of porosity and timing of vessel wall lignification of the earlywood and there is a big variation in the timing within some of the species.

The time of lignification of the first-formed stem vessels in relation to the time of leaf appearance was earlier in a ring-porous deciduous Quercus serrata than in diffuse-porous deciduous Liquidambar 
S. Takahashi \& E. Takahashi - 7 -

styraciflua, and evergreen Cinnamomum camphora, Symplocos prunifolia, Quercus glauca and Q. myrsinifolia (Fig. 4). Acanthopanax sciadophylloides, Castanopsis cuspidata and Ilex pedunculosa followed a time pattern of vessel lignification overlapping with that of ring-porous and diffuse-porous deciduous species (Fig. 4).

\section{Timing of stem and twig vessel lignification}

The timing of lignification in the first-formed stem vessels relative to twig vessels is summarized in Figure 5, and ranges between nearly simultaneous with and 14 weeks after lignification in the first-formed twig vessels. Vessel lignification in twigs occurs earlier than in stems, with hardly any overlap with timing in stems.

\section{Discussion}

Comparison among species with different and intergrading porosities

In this study, we found that the lignification of the first-formed vessels in twigs occurred concurrently with leaf appearance in both deciduous and evergreen species and in the various types of porosity (Fig. 3). This suggests that twig vessel lignification follows a similar time pattern as in the typical ring-porous deciduous Quercus serrata and the typical diffuse-porous deciduous Liquidambar styraciflua (Fig. 3). These results are consistent with previous findings. Twig vessel elements begin to lignify before bud break (Zasada \& Zahner 1969), and cambial cell division at bud bases begins before or simultaneously with bud break in both ring-porous and diffuse-porous deciduous species (Ladefoged 1952).

Lignification of the first-formed stem vessels occurred shortly after leaf appearance in the typical ring-porous deciduous $Q$. serrata and long after leaf appearance in the typical diffuse-porous deciduous L. styraciflua (Fig. 4). These results are similar to previous findings (Ladefoged 1952; Suzuki et al. 1996, 2000; Takahashi et al. 2013). However, if one considers the timing in other deciduous and evergreen diffuse-porous, semi-ring-porous, ring-porous or radial-porous species (Fig. 4) the pattern becomes more complex or even blurred.

Acanthopanax sciadophylloides is categorized as semi-ring-porous (FFPRI website). In this study, $A$. sciadophylloides has narrower earlywood vessels compared to ring-porous species, and sometimes its 
S. Takahashi \& E. Takahashi - 8 -

rings are diffuse-porous (Fig. 2e). Some of A. sciadophylloides individuals produced leaves and stem vessels for a short period, similarly to ring-porous deciduous species, while other individuals produced leaves and stem vessels for a long period, similarly to diffuse-porous deciduous species (Fig. 3-5). Tyloses are present in old sapwood rings of A. sciadophylloides (Saitoh et al. 1993), so it is possible that A. sciadophylloides transports water in several annual rings. However, Umebayashi et al. (2008) categorized A. sciadophylloides as a ring-porous species, given that its wide vessels are known to transport water mostly during the year in which they are formed, similarly to other ring-porous species. Thus, it seems that changes in water distribution pattern within annual rings affect the timing of vessel formation in relation to leaf appearance in the semi-ring-porous deciduous A. sciadophylloides.

Castanopsis cuspidata has (semi-)ring-porous to radial-porous wood (Wheeler et al. 1989; InsideWood 2004-onwards; FFPRI website). In this study, the first-formed stem vessels lignified not only long after but also simultaneous with leaf appearance in this species (Fig. 4). Hirano (1998) reported that secondary wall deposition in stems was completed concurrently with leaf appearance in Castanopsis sieboldii, a member of the same group. On the other hand, tyloses of $C$. sieboldii are present in old sapwood rings (Saitoh et al. 1993), so it is possible that C. sieboldii transport water in several annual rings. These results suggest that the species categorized as semi-ring-porous, ring-porous or radial-porous, such as Castanopsis spp., have a broad range of timing of vessel lignification in the stems, overlapping with the timing in ring-porous and diffuse-porous deciduous species.

Cinnamomum camphora is categorized as semi-ring-porous to diffuse-porous (Wheeler et al. 1989; FFPRI website), whose earlywood vessels are wider than in other diffuse-porous species (Fig. 1b, 2g-i). In this study, evergreen Cinnamomum camphora produced leaves and stem vessels for a long period, similar to diffuse-porous deciduous species (Fig. 4). Pterocarya rhoifolia, which is also categorized as semi-ring-porous to diffuse-porous (Wheeler et al. 1989; InsideWood 2004-onwards; FFPRI website), also produces leaves and stem vessels for a long period (Takahashi et al. 2013). These results suggest that semi-ring-porous to diffuse-porous evergreen species have a time pattern of stem vessel lignification similar to diffuse-porous deciduous species. Ilex pedunculosa and Symplocos prunifolia are diffuse-porous (Fig. 2h, i) (Wheeler et al. 1989; FFPRI website). Stem vessel lignification in relation to leaf appearance in I. pedunculosa occurred earlier than in Cinnamomum camphora and S. prunifolia 
(Fig. 4). Especially, stem vessel lignification of a few I. pedunculosa individuals was not different from ring-porous deciduous species (Fig. 4). Diffuse-porous Fagus sylvatica has been shown to complete vessel wall deposition in stems 2 weeks after leaf expansion (Čufar et al. 2008). These results suggest that a few diffuse-porous trees show stem vessel lignification and leaf appearance occurring within a short time, while the majority take a long time.

Quercus glauca and Q. myrsinifolia are categorized as diffuse-porous to radial-porous (Gasson 1985; Wheeler et al. 1989; FFPRI website; Noshiro \& Sasaki 2011). Stem vessel lignification occurred long after leaf appearance in Q. glauca and Q. myrsinifolia (Fig. 4). Additionally, vessels in several rings adjacent to the cambium retain their water transport ability for multiple years in radial-porous evergreen species (Hirose et al. 2005; Umebayashi et al. 2010). This suggests that the time of stem vessel lignification in radial-porous evergreen plants may be similar to that in diffuse-porous deciduous species. However, Hirano (1998) also showed that secondary wall deposition in stems was completed concurrent with leaf appearance in the radial-porous evergreen species Lithocarpus edulis. It is suggested that some species or trees might need current year's stem vessels at the time of leaf appearance.

Our study shows that the timing of stem vessel differentiation in semi-ring-porous deciduous species overlaps with that of ring-porous deciduous species and diffuse-porous deciduous species. Evergreen species showed a great variation in the timing of stem vessel lignification, relative to leaf flushing. The various types of porosity of deciduous and evergreen species clearly intergrade and overlap in their timing of lignification of the first earlywood vessels. This contradicts the hypothesis that different porosities affect the timing of vessel formation in relation to leaf appearance, especially in evergreen species and semi-ring-porous species.

\section{Acknowledgments}

We thank the staff of the Kamigamo Experimental Forest Station and of the Field Science Education and Research Center of Kyoto University for allowing access to the tree specimens and providing meteorological data. Our special thanks go to Professor Emeritus T. Nobuchi and Associate Professor N. 
S. Takahashi \& E. Takahashi - 10 -

Okada of the Forest Utilization Laboratory, Graduate School of Agriculture, Kyoto University, for helping us with sample tree selection or sample collection and for their helpful suggestions. We thank Professor K. Takabe and Associate Professor A. Yoshinaga at the Tree Cell Biology Laboratory, Graduate School of Agriculture, Kyoto University, for helping us with the phloroglucinol-hydrochloric acid reaction. We thank Mr. I. Nakane, a staff member at the Kamigamo Experimental Forest Station, for twig collection from high trees and Mr. Y. Miura for assisting us with sample collection. We also thank all of the students at the Forest Utilization Laboratory, Graduate School of Agriculture, Kyoto University, for their assistance at various stages of the study. Our special thanks go to Professor A. Osawa at the Forest Utilization Laboratory, for his critical reading of the manuscript and his helpful suggestions. We are very grateful to Professor P. Baas and referees for their constructive comments and suggestions.

\section{References}

Chaney WR \& Kozlowski TT. 1977. Patterns of water movement in intact and excised stems of Fraxinus americana and Acer saccharum seedlings. Ann. Bot. 41: 1093-1100.

Čufar K, Prislan P, De Luis M \& Gričar J. 2008. Tree-ring variation, wood formation and phenology of beech (Fagus sylvatica) from a representative site in Slovenia, SE Central Europe. Trees 22: 749-758.

Ellmore GS \& Ewers FW. 1986. Fluid flow in the outermost xylem increment of a ring-porous tree, Ulmus americana. Amer. J. Bot. 73: 1771-1774.

FFPRI website. http://f030091.ffpri.affrc.go.jp/IDB-E/home.php. Accessed 20 August 2015.

Forest Research Station of Graduate School of Agriculture, Kyoto University. 2007. Meteorological observations in Kyoto University forests No. 14, 2001-2005 (in Japanese).

Fromm J. 2013. Cellular aspects of wood formation. Springer, Heidelberg, Dordrecht, London. 
S. Takahashi \& E. Takahashi - 11 -

Fukushima K, Funada R, Sugiyama J, Takabe K, Umezawa T \& Yamamoto H. 2003. Secondary xylem formation - Introduction to biomass science. Kaiseisha Press (in Japanese).

Gasson P. 1985. Automatic measurement of vessel lumen area and diameter with particular reference to pedunculate oak and common beech. IAWA Bull. n.s. 6: 219-237.

González-González BD, García-González I \& Vázquez-Ruiz RA 2013. Comparative cambial dynamics and phenology of Quercus robur L. and Q. pyrenaica Willd. in an Atlantic forest of the northwestern Iberian Peninsula. Trees 27: 1571-1585.

Greenidge KNH. 1955. Studies in the physiology of forest trees. III. The effect of drastic interruption of conducting tissues on moisture movement. Amer. J. Bot. 42: 582-587.

Hayashi S. 1991. Micrographic atlas of Japanese woods. Wood Research Institute, Kyoto University 23: 1-147 (in Japanese).

Hayashi Y, Furusato K \& Nakamura T. 1987. Illustrated trees in color. Hokuryukan, Japan (in Japanese).

Hirano R. 1998. Phenological wood formation in ring- and diffuse-porous broad-leaved tree species. Master's thesis (in Japanese).

Hirose S, Kume A, Takeuchi S, Utsumi Y, Otsuki K \& Ogawa S. 2005. Stem water transport of Lithocarpus edulis, an evergreen oak with radial-porous wood. Tree Physiol. 25: 221-228. 
S. Takahashi \& E. Takahashi - 12 -

Imagawa H \& Ishida S. 1972. Study on the wood formation in trees: Report II. Development of the vessel in earlywood of hari-giri, Kalopanax pictus. Res. Bull. Coll. Exp. For. Hokkaido Univ. 29: 55-72 (in Japanese with English summary).

InsideWood. 2004-onwards. Published on the internet (http://insidewood.lib.ncsu.edu/search). Accessed 20 August 2015.

Itoh T. 1995. Anatomical description of Japanese hardwoods I. Reprinted from wood research and technical notes No. 31: 81-181. Wood Research Institute, Kyoto University, Uji, Kyoto, Japan (in Japanese).

Itoh T. 1998. Anatomical description of Japanese hardwoods IV. Reprinted from wood research and technical notes No. 34: 30-166. Wood Research Institute, Kyoto University, Uji, Kyoto, Japan (in Japanese).

Kikuzawa K. 1983. Leaf survival of woody plants in deciduous broad-leaved forests. 1. Tall trees. Can. J. Bot. 61: 2133-2139.

Kudo K, Yasue K, Hosoo Y \& Funada R. 2015. Relationship between formation of earlywood vessels and leaf phenology in two ring-porous hardwoods, Quercus serrata and Robinia pseudoacacia, in early spring. J Wood Sci. (doi 10.1007/s10086-015-1487-6).

Ladefoged K. 1952. The periodicity of wood formation. Dan. Biol. Skr. 7: 1-98.

Lechowicz MJ. 1984. Why do temperate deciduous trees leaf out at different times? Adaptation and ecology of forest communities. Amer. Nat. 124: 821-842. 
S. Takahashi \& E. Takahashi - 13 -

Noshiro S \& Sasaki Y. 2011. Identification of Japanese species of evergreen Quercus and Lithocarpus (Fagaceae). IAWA J. 32: 383-393.

Saitoh T, Ohtani J \& Fukazawa K. 1993. The occurrence and morphology of tyloses and gums in the vessels of Japanese hardwoods. IAWA J. 14: 359-371.

Sass JE. 1951. Botanical microtechnique, Ed. 2: 69-71. The Iowa State College Press, USA.

Sass-Klaassen U, Sabajo CR \& den Ouden J. 2011. Vessel formation in relation to leaf phenology in pedunculate oak and European ash. Dendrochronologia 29: 171-175.

Scholz A, Stein A. Choat B \& Jansen S. 2014. How drought and deciduousness shape xylem plasticity in three Costa Rican woody plant species. IAWA J. 35: 337-355.

Suzuki M, Hirano R \& Yoda K. 2000. Phenological analysis of wood formation in temperate deciduous ring and diffuse porous wood. Chonnam National Univ. Press, Kwangju. Printed in Korea, reprint from Kim YS (ed.), New horizons in wood anatomy: 132-137.

Suzuki M, Yoda K \& Suzuki H. 1996. Phenological comparison of the onset of vessel formation between ring-porous and diffuse-porous deciduous trees in a Japanese temperate forest. IAWA J. 17: 431-444.

Takahashi S, Okada N \& Nobuchi T. 2008. Examination of wood sampling method with an increment borer: An investigation of seasonal changes in vessel formation. Forest Research, Kyoto 77: 123-128.

Takahashi S, Okada N \& Nobuchi T. 2013. Relationship between the timing of vessel formation and leaf phenology in ten ring-porous and diffuse-porous deciduous tree species. Ecol. Res. 28: 615-624. 
S. Takahashi \& E. Takahashi - 14 -

Takahashi S, Okada N \& Nobuchi T. 2015. Relationship between vessel porosity and leaf emergence pattern in ring- and diffuse-porous deciduous trees in a temperate hardwood forest. Botany 93: 31-39.

Umebayashi T, Utsumi Y, Koga S, Inoue S, Fujikawa S, Arakawa K, Matsumura J \& Oda K. 2008. Conducting pathways in north temperate deciduous broadleaved trees. IAWA J. 29: 247-263.

Umebayashi T, Utsumi Y, Koga S, Inoue S, Matsumura J, Oda K, Fujikawa S, Arakawa K \& Otsuki K. 2010. Xylem water-conducting patterns of 34 broadleaved evergreen trees in southern Japan. Trees 24: $571-583$.

Utsumi Y, Sano Y, Fujikawa S, Funada R \& Ohtani J. 1998. Visualization of cavitated vessels in winter and refilled vessels in spring in diffuse-porous trees by cryo-scanning electron microscopy. Plant Physiol. 117: 1463-1471.

Utsumi Y, Sano Y, Funada R, Fujikawa S \& Ohtani J. 1999. The progression of cavitation in earlywood vessels of Fraxinus mandshurica var. japonica during freezing and thawing. Plant Physiol. 121: 897-904.

Wakuta R, Saiki H \& Harada H. 1973. Enlarging of differentiating vessel element in Firmiana platanifolia Schott et Endl. Bull. Kyoto Univ. For. 34: 204-216 (in Japanese with English summary).

Wheeler EA, Baas P \& Gasson PE. 1989. IAWA list of microscopic features for hardwood identification with an appendix on non-anatomical information. IAWA Bull. n.s. 10: 219-332.

Zasada JC \& Zahner R. 1969. Vessel element development in the earlywood of red oak (Quercus rubra).

Can. J. Bot. 47: 1965-1971. 
S. Takahashi \& E. Takahashi - 15 -

\section{Table captions}

Table 1. Description of the tree species sampled.

${ }^{a}$ Classes of porosity were defined based on the FFPRI website, InsideWood (2004-onwards), Gasson (1985), Wheeler et al. (1989) and Noshiro \& Sasaki (2011). Castanopsis cuspidata is characterized as (semi-)ring-porous to radial-porous species. Evergreen diffuse-porous species are categorized as diffuse-porous with very weak to more pronounced semi-ring-porous tendencies.

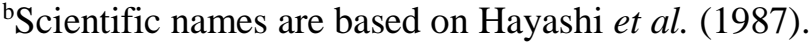

${ }^{\mathrm{c}}$ Diameter at breast height.

${ }^{\mathrm{d}} \mathrm{O}$ : twigs were sampled of this tree. 
S. Takahashi \& E. Takahashi - 16 -

\section{Figure captions}

Figure 1. Light micrographs of cross sections in deciduous $(a, b)$ and evergreen $(c, d)$ sample trees. - a: Quercus serrata; black arrow, a wide vessel in the pore zone; white arrow, a narrow vessel in the non-pore zone. - b: Liquidambar styraciflua. - c: Quercus glauca. - d: Quercus myrsinifolia. - Ring borders are marked. - Scale bar is $300 \mu \mathrm{m}$.

Figure 2. Light microphotographs of cross sections in deciduous (e) and evergreen (f-i) sample trees. e: Acanthopanax sciadophylloides; arrowhead, a relatively wide vessel. - f: Castanopsis cuspidata; black arrow, a relatively wide vessel; white arrow, relatively narrow vessels. - g: Cinnamomum camphora. - h: Ilex pedunculosa. - i: Symplocos prunifolia. - Ring borders are marked. - Scale bar is $300 \mu \mathrm{m}$.

Figure 3. Timing of lignification of the first-formed vessels in twigs relative to the time of leaf appearance in 2006. Numbers in parentheses indicate the number of trees; bars indicate the time ranges.

Figure 4. Timing of lignification of the first-formed vessels in stems relative to the time of leaf appearance in 2006. Numbers in parentheses indicate the numbers of trees; - - represents a single tree that had not yet completed lignification; bars indicate the time ranges.

Figure 5. Timing of lignification of the first-formed vessels in stems compared to twigs in 2006. Numbers in parentheses indicate the numbers of trees; - - represents a single tree that had not yet completed lignification; bars indicate the time ranges. 
Table 1 Description of the tree species sampled.

\begin{tabular}{|c|c|c|c|c|c|c|c|}
\hline Leaf habit & Porosity $^{\mathrm{a}}$ & Species $^{\mathrm{b}}$ & Family & Tree No. & $\begin{array}{l}\mathrm{DBH}^{\mathrm{c}} \\
(\mathrm{cm})\end{array}$ & $\begin{array}{l}\text { Tree height } \\
\text { (m) }\end{array}$ & Twig $^{\mathrm{d}}$ \\
\hline \multirow[t]{17}{*}{ Deciduous } & Ring-porous & Quercus serrata Thunb. & Fagaceae & 149 & 32 & 14 & \\
\hline & & & & 156 & 23 & 8 & $\mathrm{O}$ \\
\hline & & & & 157 & 36 & 12 & $\mathrm{O}$ \\
\hline & & & & 158 & 33 & 14 & $\mathrm{O}$ \\
\hline & & & & 159 & 22 & 13 & \\
\hline & Diffuse-porous & Liquidambar styraciflua $\mathrm{L}$. & Hamamelidaceae & 182 & 30 & 25 & $\mathrm{O}$ \\
\hline & & & & 183 & 22 & 22 & $\mathrm{O}$ \\
\hline & & & & 184 & 33 & 25 & \\
\hline & & & & 185 & 40 & 29 & \\
\hline & & & & 186 & 44 & 24 & $\mathrm{O}$ \\
\hline & & & & 187 & 56 & 29 & $\mathrm{O}$ \\
\hline & Semi-ring-porous & Acanthopanax sciadophylloides & Araliaceae & 164 & 21 & 7 & $\mathrm{O}$ \\
\hline & & Fr. et Sav. & & 165 & 16 & 7 & $\mathrm{O}$ \\
\hline & & & & 170 & 22 & 13 & \\
\hline & & & & 173 & 21 & 13 & $\mathrm{O}$ \\
\hline & & & & 177 & 27 & 14 & $\mathrm{O}$ \\
\hline & & & & 178 & 29 & 17 & $\mathrm{O}$ \\
\hline \multirow[t]{26}{*}{ Evergreen } & ring- (or radial-) & Castanopsis cuspidata (Thunb.) & Fagaceae & 167 & 56 & 26 & $\mathrm{O}$ \\
\hline & porous & Schottky & & 168 & 39 & 23 & $\mathrm{O}$ \\
\hline & & & & 169 & 12 & 7 & $\mathrm{O}$ \\
\hline & Diffuse-porous & Cinnaтотит camphora Sieb. & Lauraceae & 171 & 45 & 19 & $\mathrm{O}$ \\
\hline & & & & 172 & 29 & 16 & $\mathrm{O}$ \\
\hline & & & & 176 & 35 & 15 & $\mathrm{O}$ \\
\hline & & Ilex pedunculosa Miq. & Aquifoliaceae & 153 & 22 & 9 & $\mathrm{O}$ \\
\hline & & & & 161 & 24 & 8 & $\mathrm{O}$ \\
\hline & & & & 162 & 19 & 10 & $\mathrm{O}$ \\
\hline & & & & 163 & 21 & 11 & $\mathrm{O}$ \\
\hline & & & & 166 & 24 & 9 & \\
\hline & & Symplocos prunifolia Sieb. et Zucc. & Symplocaceae & 150 & 24 & 7 & $\mathrm{O}$ \\
\hline & & & & 151 & 19 & 9 & $\mathrm{O}$ \\
\hline & & & & 152 & 21 & 9 & $\mathrm{O}$ \\
\hline & & & & 154 & 22 & 9 & $\mathrm{O}$ \\
\hline & & & & 155 & 22 & 8 & $\mathrm{O}$ \\
\hline & Radial-porous & Quercus glauca Thunb. & Fagaceae & 160 & 24 & 11 & $\mathrm{O}$ \\
\hline & & & & 174 & 29 & 13 & $\mathrm{O}$ \\
\hline & & & & 175 & 20 & 12 & \\
\hline & & & & 180 & 27 & 13 & $\mathrm{O}$ \\
\hline & & & & 181 & 44 & 17 & $\mathrm{O}$ \\
\hline & & Quercus myrsinifolia Blume & Fagaceae & 144 & 22 & 17 & $\mathrm{O}$ \\
\hline & & & & 145 & 22 & 17 & \\
\hline & & & & 146 & 28 & 15 & $\mathrm{O}$ \\
\hline & & & & 147 & 53 & 20 & $\mathrm{O}$ \\
\hline & & & & 148 & 30 & 20 & $\mathrm{O}$ \\
\hline
\end{tabular}

${ }^{a}$ Classes of porosity were defined based on the FFPRI website, InsideWood (2004-onwards), Gasson (1985), Wheeler et al. (1989) and Noshiro \& Sasaki (2011). Castanopsis cuspidata is characterized as (semi-)ring-porous to radial-porous species. Evergreen diffuse-porous species are categorized as diffuse-porous with very weak to more pronounced semi-ring-porous tendencies.

${ }^{\mathrm{b}}$ Scientific names are based on Hayashi et al. (1987).

${ }^{\mathrm{c}}$ Diameter at breast height.

${ }^{\mathrm{d} O} \mathrm{O}$ : twigs were sampled of this tree. 


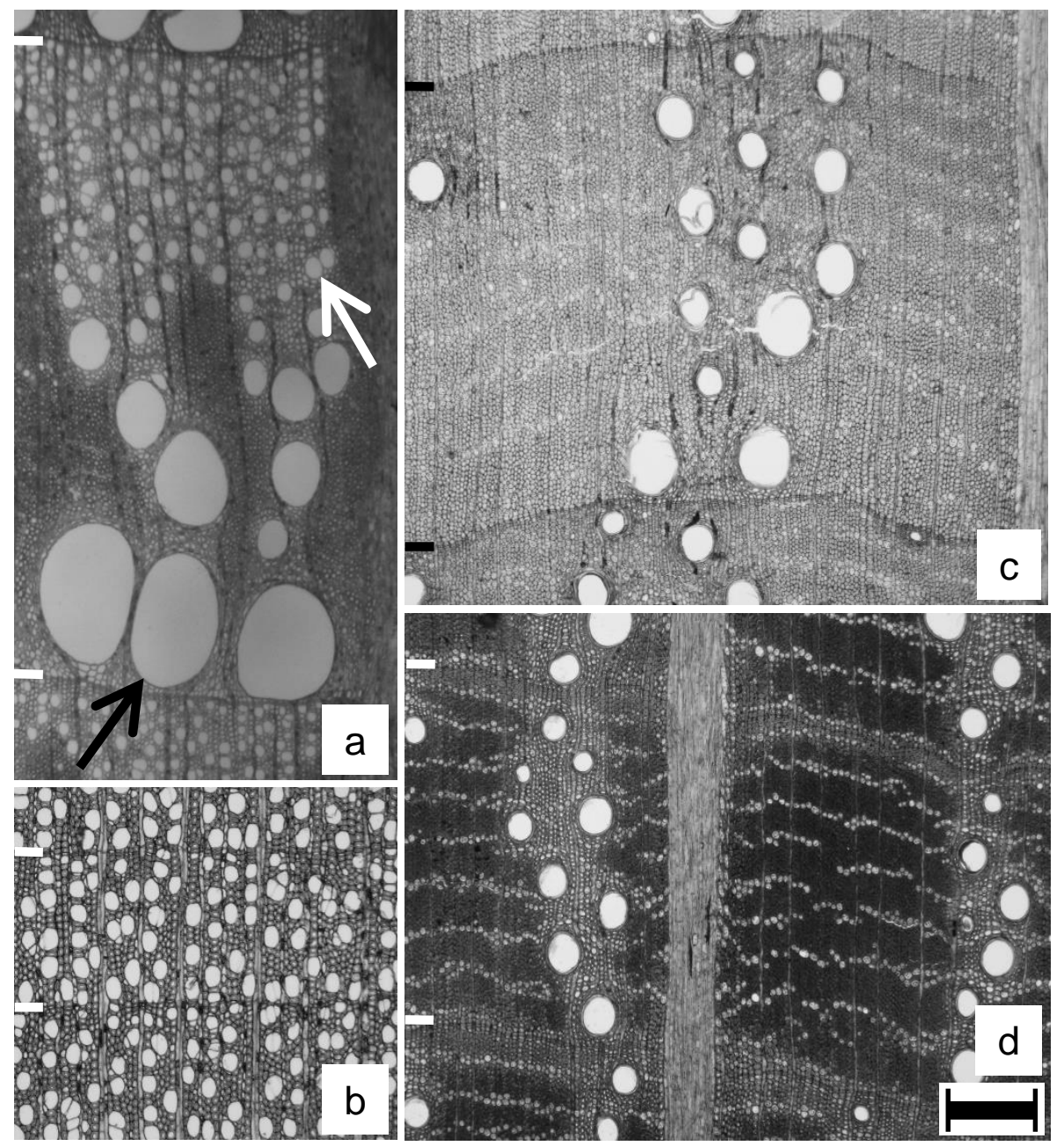

Figure 1. Light micrographs of cross sections in deciduous (a,b) and evergreen (c,d) sample trees. - a: Quercus serrata; black arrow, a wide vessel in the pore zone; white arrow, a narrow vessel in the non-pore zone. - b: Liquidambar styraciflua. - c: Quercus glauca. - d: Quercus myrsinifolia. - Ring borders are marked. - Scale bar is $300 \mu \mathrm{m}$. 

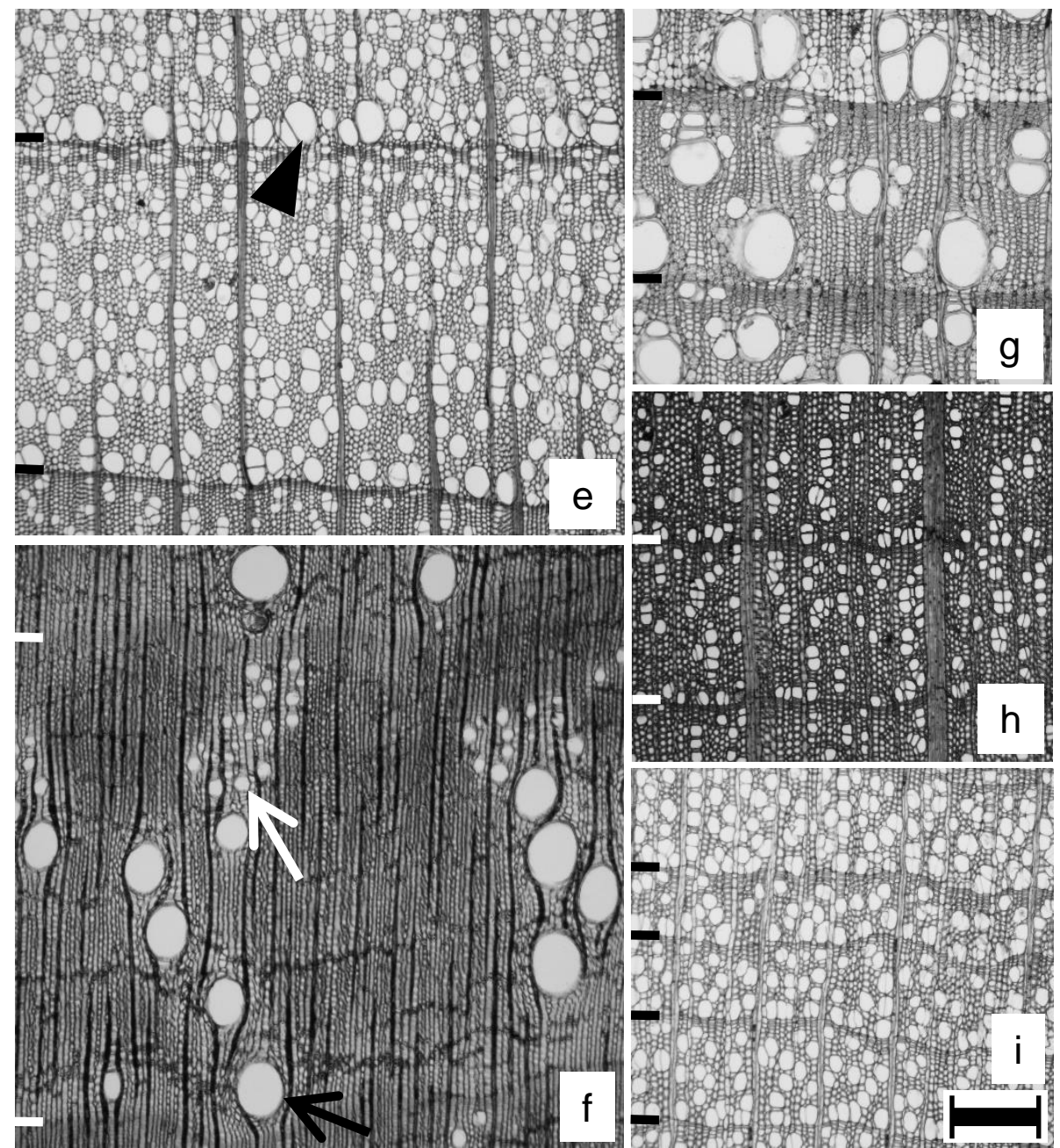

Figure 2. Light microphotographs of cross sections in deciduous (e) and evergreen (fi) sample trees. - e: Acanthopanax sciadophylloides; arrowhead, a relatively wide vessel. - f: Castanopsis cuspidata; black arrow, a relatively wide vessel; white arrow, relatively narrow vessels. - g: Cinnamomum camphora. - h: Ilex pedunculosa. - i: Symplocos prunifolia. - Ring borders are marked. - Scale bar is $300 \mu \mathrm{m}$. 


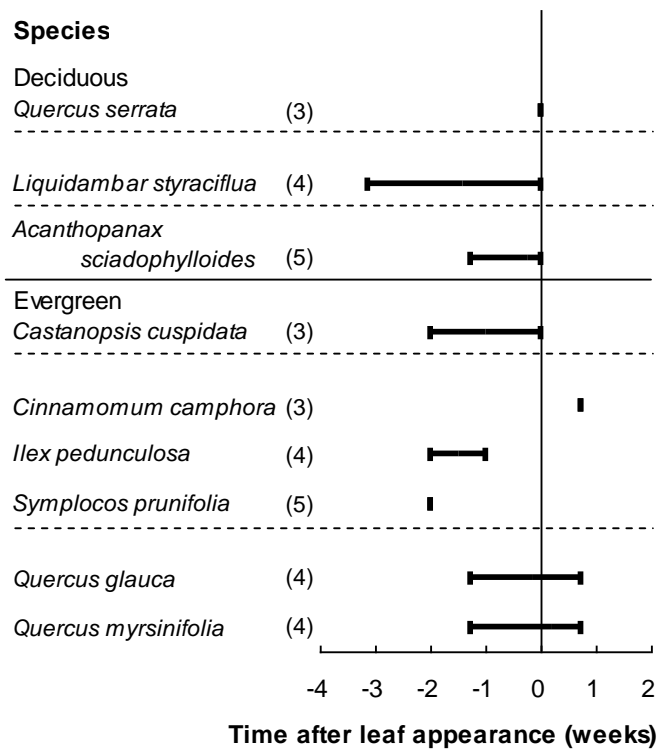

Figure 3. Timing of lignification of the first-formed vessels in twigs relative to the time of leaf appearance in 2006. Numbers in parentheses indicate the number of trees; bars indicate the time ranges. 


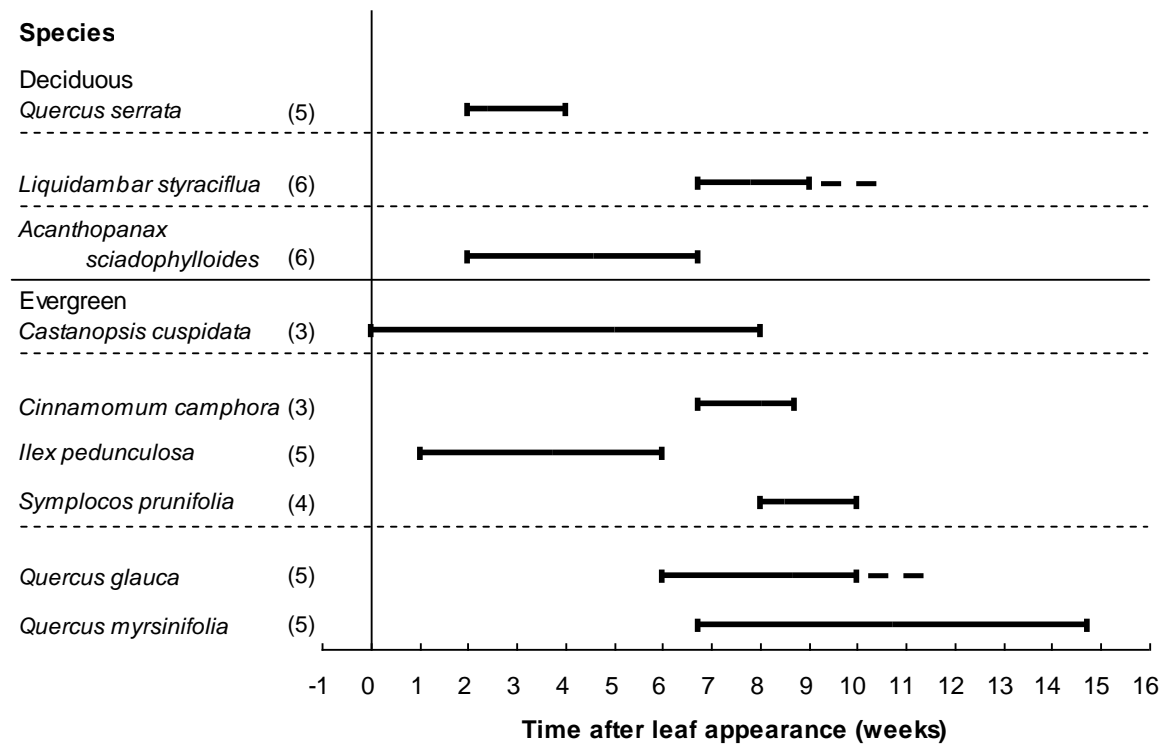

Figure 4. Timing of lignification of the first-formed vessels in stems relative to the time of leaf appearance in 2006. Numbers in parentheses indicate the numbers of trees; - - represents a single tree that had not yet completed lignification; bars indicate the time ranges. 


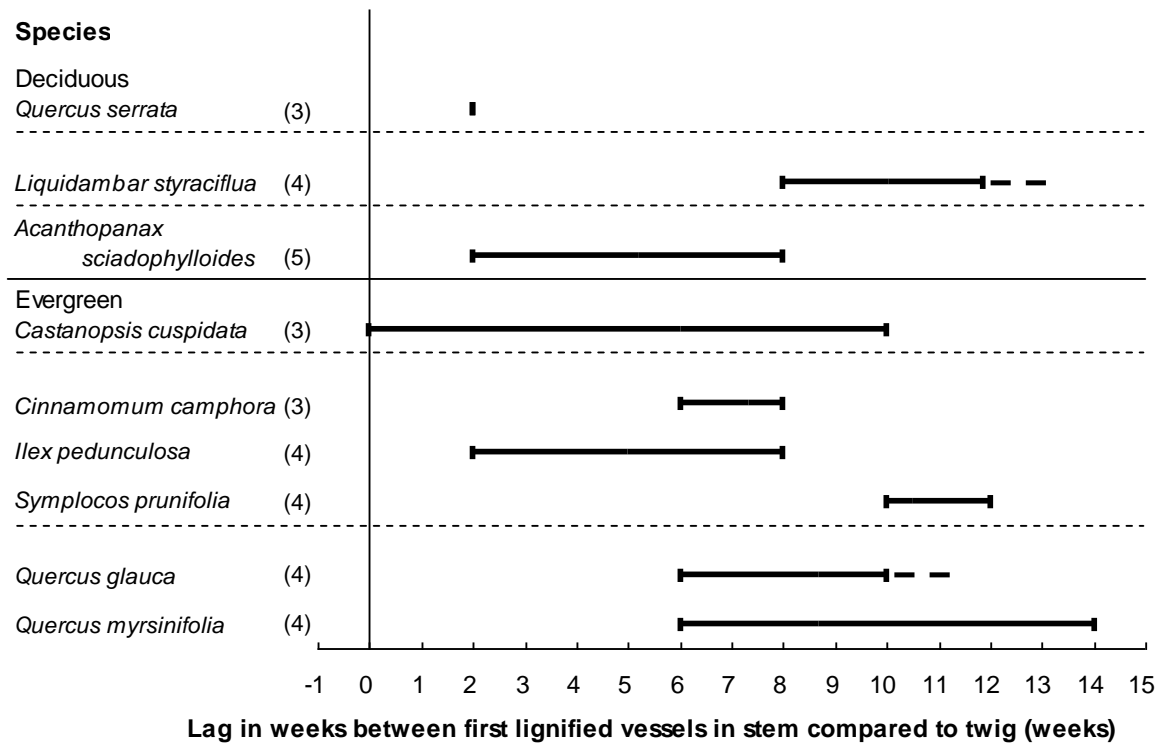

Figure 5. Timing of lignification of the first-formed vessels in stems compared to twigs in 2006. Numbers in parentheses indicate the numbers of trees; - - represents a single tree that had not yet completed lignification; bars indicate the time ranges. 